\title{
АКАДЕМІЧНА ТА УНІВЕРСИТЕТСЬКА НАУКА - ШКОЛІ
}

\author{
26 лютого 2020 р., м. Переяслав-Хмельницький, Україна
}

https://doi.org/10.37472/2707-305X-2020-2-1-3-2

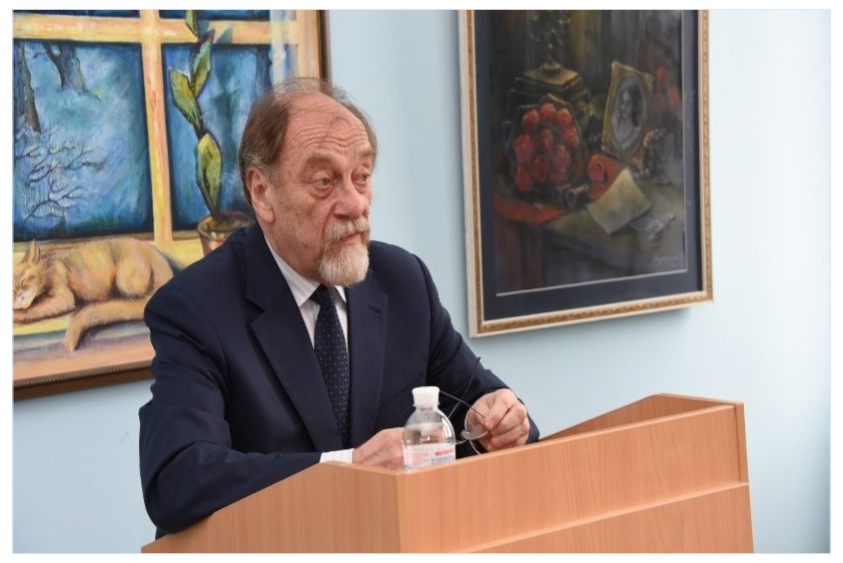

ЛЯШЕНКО Олександр Іванович

доктор педагогічних наук, професор,

дійсний член (академік) НАПН України, академік-секретар Відділення загальної середньої освіти Національної академії педагогічних наук України, м. Київ, Україна

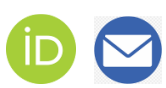

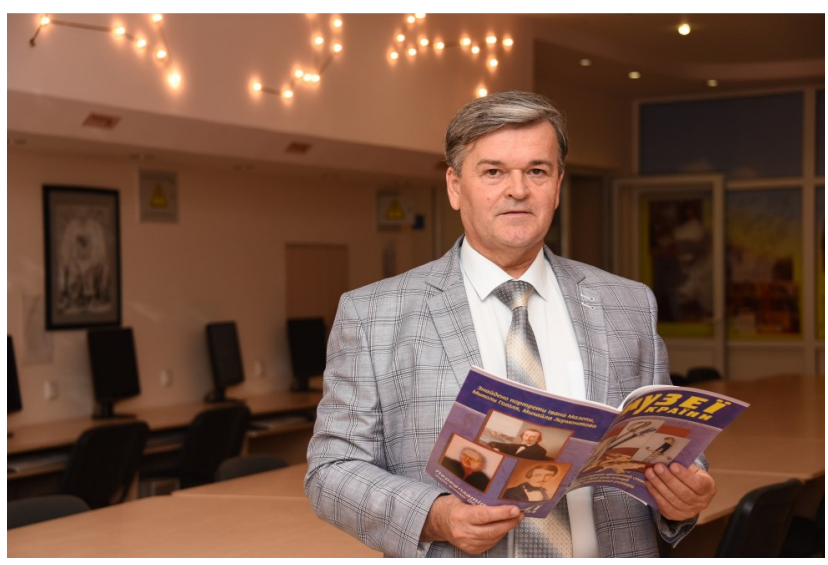

КОЦУР Віктор Петрович

доктор історичних наук, профессор, дійсний член (академік) НАПН України, ректор Переяслав-Хмельницького державного педагогічного університету імені Григорія Сковороди, м. Переяслав-Хмельницький, Україна

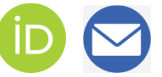

Анотація. Подається інформація про виїзне засідання Відділення загальної середньої освіти Національної академії педагогічних наук України до Переяслав-Хмельницького державного педагогічного університету імені Григорія Сковороди. Відділення і університет поєднують давні наукові зв'язки, одним із проявів яких $\epsilon$ проведення тематичних науково-практичних сесій. Цього року така сесія була присвячена проблемам трансформаційних прочесів у Новій українській школі. Учені академії і викладачі університету обговорили нагальні питання реформування загальної середньої освіти, обмінялися досвідом з упровадження результатів наукових досліджень в освітню практику. Учасники сесії ознайомилися з роботою педагогічного факультету університету, його інноваційними лабораторіями і центрами.

Ключові слова: Національна академія педагогічних наук України; Переяслав-Хмельницький державний педагогічний університет імені Григорія Сковороди; академічна наука; університетська наука; Нова українська школа.

Між Національною академією педагогічних наук України і Переяслав-Хмельницький державний педагогічний університет імені Григорія Сковороди давно встановлено міцні наукові зв'язки. Академія допомагає університету в проведенні педагогічних досліджень, підготовці науково-педагогічних кадрів тощо. На базі університету проведено багато спільних науковопрактичних заходів, конференцій, семінарів, круглих столів. Така співпраця корисна обом сторонам, оскільки, з одного боку, вчені НАПН мають можливість апробувати свої наукові ідеї в освітній практиці, з іншого боку, студенти і викладачі спілкуються із провідними вченими й отримують від них інформацію про останні наукові пошуки і здобутки педагогічної науки.

у 2018 р. ці взаємини закріплено угодою про співпрацю між Відділенням загальної середньої освіти НАПН України і Переяслав-Хмельницький державний педагогічний університет імені Григорія Сковороди, результатом якої стали вже традиційні науково-практичні виїзні сесії з актуальних 
проблем педагогічної науки і освітянської практики.

Остання така сесія «Трансформаційні

процеси в освіті: академічна та університетська наука школі» відбулася 26 лютого 2020 р. у Переяславі-

Хмельницькому. $\mathrm{y}$ ній узяли участь шість учених Відділення: академіки $\mathrm{HAПН}$ України Н.М. Бібік,

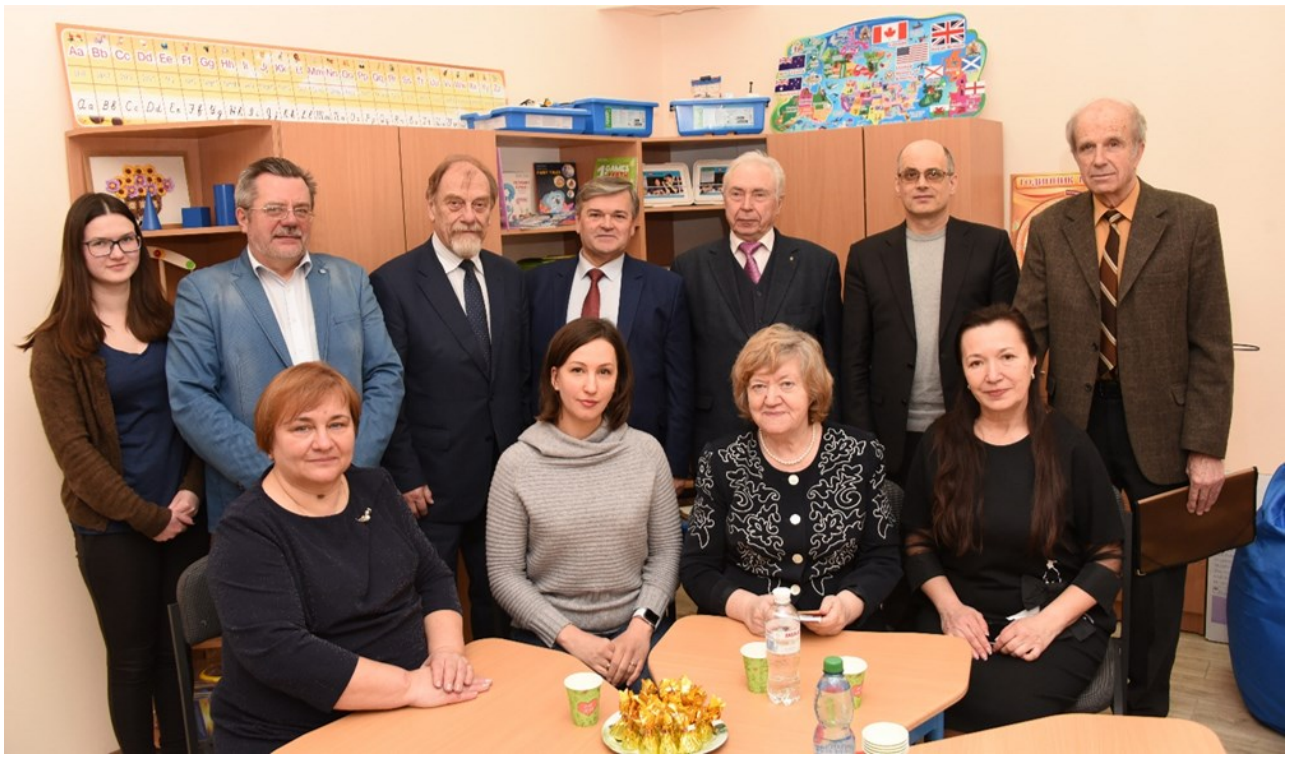
O.І. Ляшенко, М.І. Шут, члени-кореспонденти НАПН України Ю.І. Мальований, О.М. Спірін, науковий співробітник Інституту педагогіки НАПН України Н.П.Листопад. Цьогорічна науковопрактична сесія мала три локації: «Нова українська школа: перші здобутки і перспективи розвитку», «Особливості організації освітнього процесу в початковій школі», «Проблеми підготовки майбутніх учителів і науковців».

У своєму виступі перед учителями, студентами і викладачами академік НАПН України O.І. Ляшенко схарактеризував головні ідеї, покладені в основу концепції Нової української школи, акцентуючи увагу на компетентнісному підході до навчання, відмінностях нинішньої парадигми освіти від попередньої. Він окреслив також нагальні проблеми в модернізації змісту освіти, підготовці державного стандарту базової середньої освіти, освітніх і навчальних програм для гімназій, закликав учителів активніше долучатися до громадського обговорення нормативних документів.

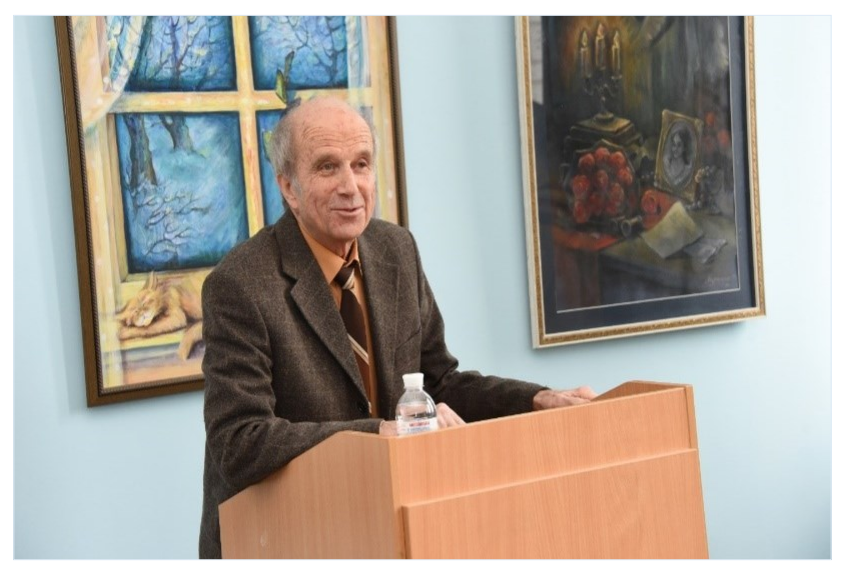

Його виступ доповнив член-кореспондент НАПН України Ю.І. Мальований, який торкнувся пріоритетних завдань сучасної шкільної освіти, зокрема проблеми розвитку мислення учнів, а також окреслив роль учителя у забезпеченні успішних освітніх перетворень і в поетичній формі звеличив педагогічну професію і постать сучасного вчителя.

Академік НАПН України Н.М. Бібік розкрила переваги і ризики інтегрованого навчання у початковій школі, особливості організації освітнього процесу під час вивчення курсу «Я досліджую світ».

Про нове навчально-методичне забезпечення математики для 3 класу розповіла автор підручника Н.П. Листопад. Вона також зупинилася на методичних проблемах учителів у процесі переходу шкіл на новий зміст. У спілкуванні з учителями, викладачами педагогічного факультету науковці обговорювали результати моніторингу навчальних досягнень молодших школярів, якість

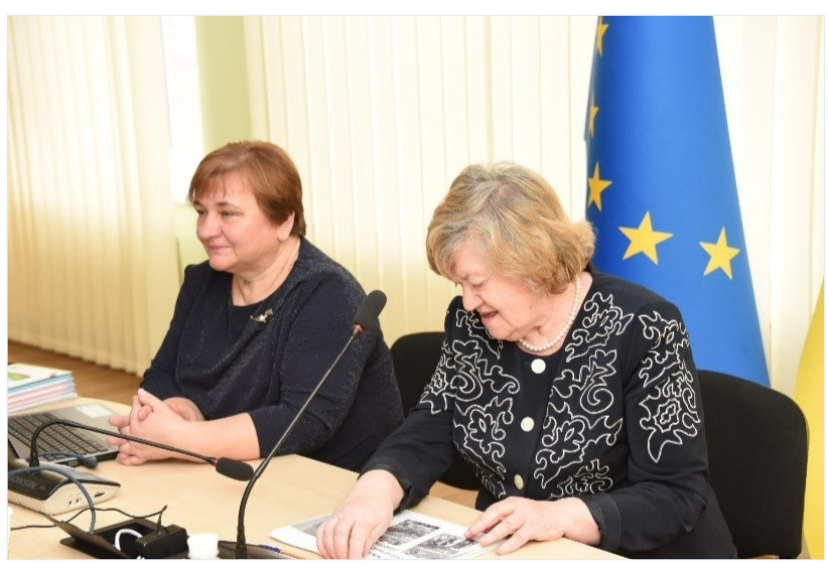




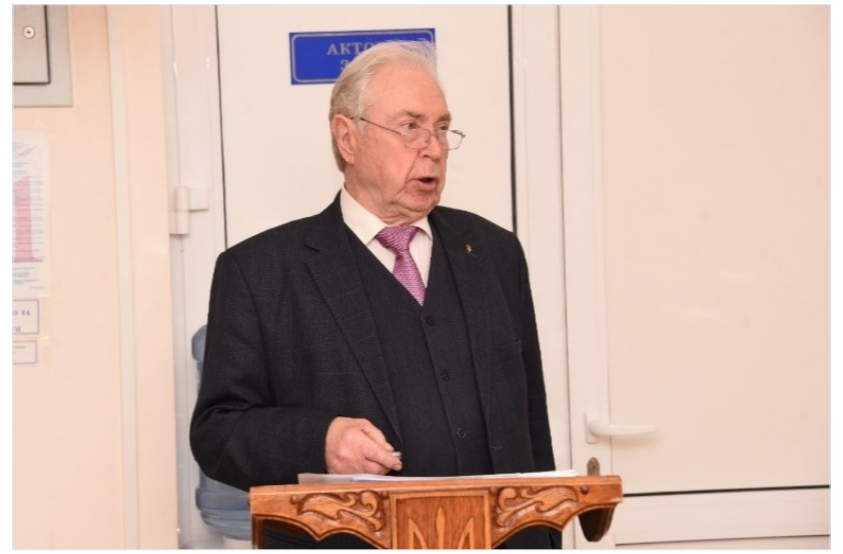

навчально-методичного забезпечення, потреби в науковому супроводі реалізації типових освітніх програм для початкової школи.

На зустрічі з викладачами, магістрантами і молодими вченими університету академік НАПН України М.І. Шут розповів про українських учених, які зробили значний внесок у розвиток сучасної природничої науки. Він підкреслив, що висвітлення в освітньому процесі здобутків української науки на прикладі життєвого та наукового шляху видатних українських учених сприятиме національно-патріотичному вихованню здобувачів освіти.

Член-кореспондент НАПН України О.М. Спірін продемонстрував на конкретних прикладах можливості електронних відкритих систем у науково-педагогічній діяльності, зокрема використання Електронної бібліотеки НАПН України для пошуку інформації з проблем педагогіки, психології та освітньої практики.

Член-кореспондент НАПН України І.І. Доброскок розповіла про роботу кафедри 3 підготовки і підвищення кваліфікації педагогічних працівників, розширення ії діяльності в напрямі професійного удосконалення фахівців різних

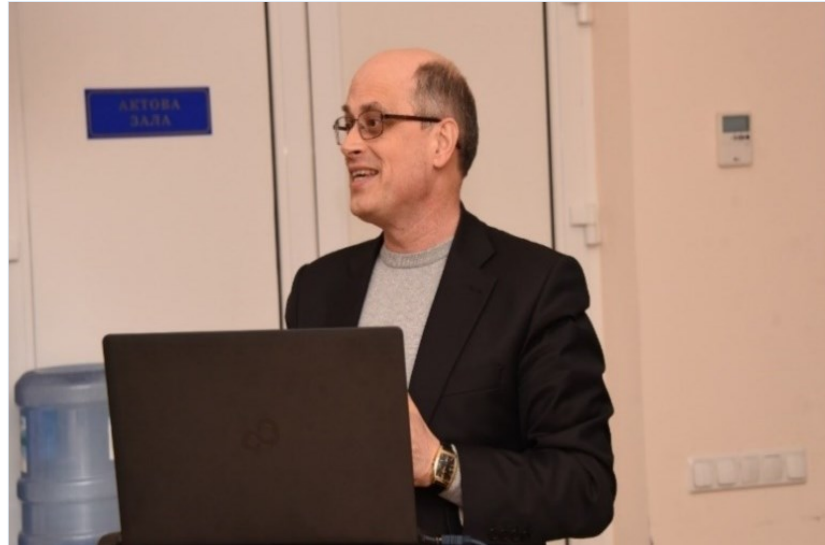

спеціальностей і залучення до цієї роботи спонсорів.

Учасники науково-практичної сесії ознайомилися з інноваційними аудиторіями, лабораторіями та центрами на педагогічному факультеті. Освітнє середовище університету сприяє здобуттю якісних освітніх послуг на базі оснащених лабораторій Нової української школи, Ресурсного центру інклюзивної освіти, Центру неперервної освіти, навчально-наукових творчих майстерень 3 образотворчого мистецтва, багатьох інших лабораторій університету, створених останнім часом за підтримки і сприяння ректора університету, академіка НАПН України В.П. Коцура.

Делегація науково-практичної сесії ознайомилася з мистецькими надбаннями освітнього процесу університету, відвідала тематичні виставки «Етнічне коріння сучасного декоративного мистецтва», «Дерево життя в українському мистецтві», "Колорит сучасного орнаменту», виставку стародавнього мистецтва витинанок і гобеленів, що відображають палітру творчих талантів креативної студентської молоді. За останні роки студенти педагогічного факультету долучилися до
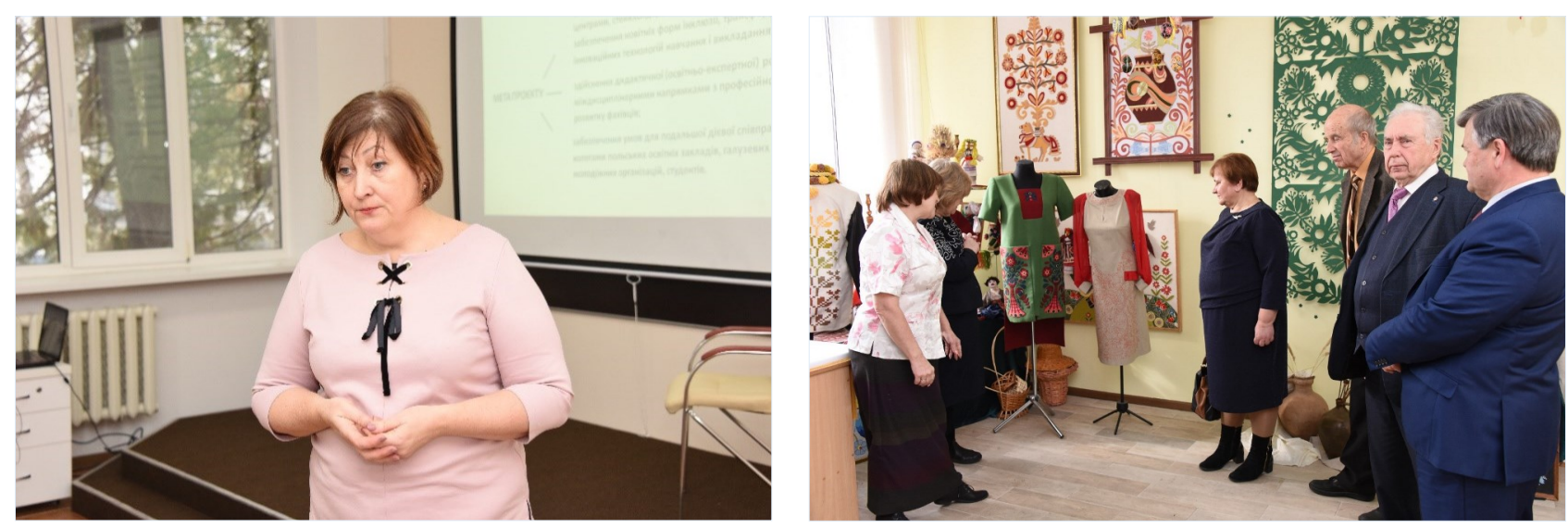
мистецьких виставок та майстер-класів і вибороли визнання у таких номінаціях:

- «Лідер вищої освіти України» - Гран-Прі та золота медаль IX Міжнародної виставки «Сучасні заклади освіти - 2018» та VII Міжнародної виставки освіти «Word Edu - 2018»;

- «Інформаційні IT-технології у вищому навчальному закладі» - Гран-Прі Міжнародної спеціалізованої виставки «Освіта та кар'єра День студента 2018» та «Освіта та кар'єра - День студента 2019»;

- "Вивчення сучасних технік як засіб інноваційного розвитку професійної освіти майбутніх учителів мистецтва» - золота медаль XI Міжнародної виставки «Інноватика в сучасній освіті».

Викладачі та студенти педагогічного факультету за сприяння та підтримки декана факультету професора Н.В. Ігнатенко демонструють високу активність у міжнародних грантових проєктах, програмах міжнародної академічної мобільності, завдяки яким реалізується Стратегія інтернаціоналізації університету. Зокрема, це відображено в роботі україно-данського табору на базі університету, в україно-чеському проєкті «Передача європейського досвіду у сфері освітнього менеджменту», міжнародному семінарі «Управління школою у суспільстві знань», форумі «Європейське майбутнє України: погляд вітчизняних та польських дослідників», інших міжнародних заходах. Керівник Міжнародного проєкту програми ЄC Erasmus+ «Модернізація педагогічної вищої освіти 3 використанням інноваційних інструментів викладання - MoPED» академік НАПН України В.П. Коцур разом із менеджером проєкту доцентом О.А. Ковтун презентували ICRкімнату - середовище для реалізації завдань і поширення результатів проєкту.

Після завершення науково-практичної сесії В.П. Коцур підбив

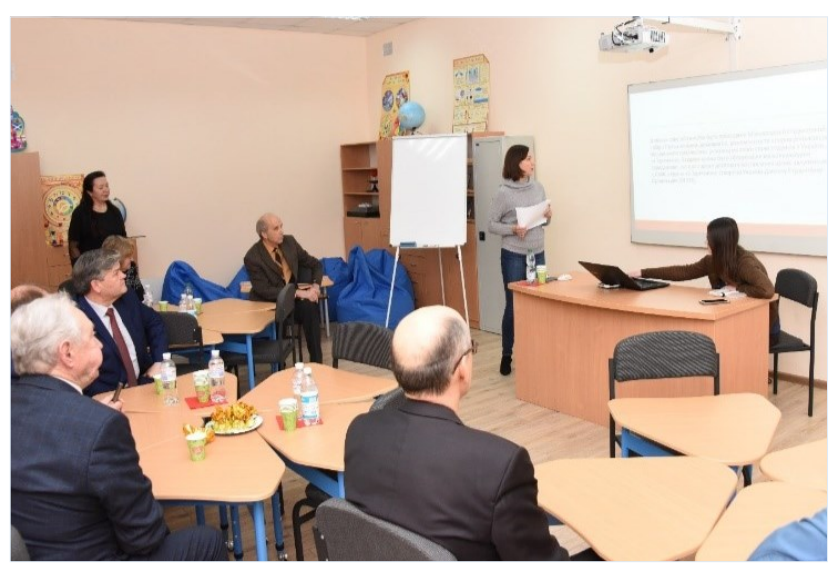

підсумки зустрічі студентів і викладачів університету та освітян Переяславщини з ученими НАПН України, підкреслив позитивні ознаки плідної співпраці Переяслав-Хмельницького державного педагогічного університету імені Григорія Сковороди з Національною академією педагогічних наук України, висловив вдячність усім учасникам науково-практичної сесії, зокрема вченим Відділення загальної середньої освіти, які приїхали до університету. Він зазначив, що ця традиція продовжуватиметься і надалі, оскільки корисна всім, хто бере в ній участь.

За одностайною думкою учених НАПН України і викладачів університету такі науково-практичної сесії мають стати регулярними, оскільки вони надають можливість для живого спілкування учених з освітянською громадою, завдяки якому кожна зі сторін отримує зиск для поліпшення своєї професійної діяльності.

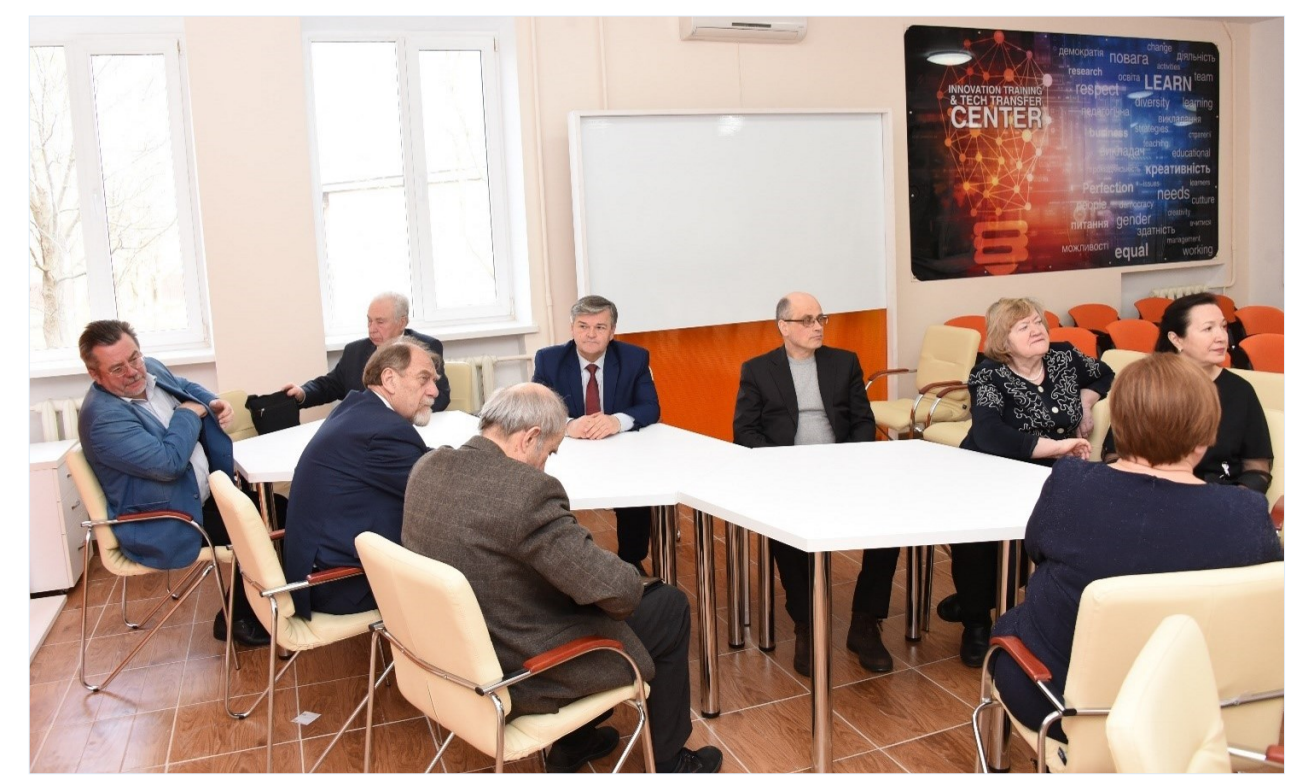




\section{ACADEMIC AND UNIVERSITY SCIENCE TO SCHOOLS}

February 26, 2020, Pereiaslav-Khmelnytskyi, Ukraine

Oleksandr Liashenko

DSc in Pedagogy, Professor, Full Member (Academician) of NAES of Ukraine, Academician Secretary of the Division of General Secondary Education, National Academy of Educational Sciences of Ukraine, Kyiv, Ukraine

Viktor Kotsur

DSc in History, Professor, Full Member (Academician) of NAES of Ukraine, Rector, Pereiaslav-Khmelnytskyi Hryhoriy Skovoroda State Pedagogical University, Pereiaslav-Khmelnytskyi, Ukraine

Abstract. The information on the on-site visit of the Division of General Secondary Education of the National Academy of Educational Sciences of Ukraine to the Pereiaslav-Khmelnytskyi Hryhoriy Skovoroda State Pedagogical University is presented. The long-standing scientific connections combine the division and the university, one of manifestations of which is carrying out the thematic scientific and practical sessions. In 2020 the session was dedicated to the problems of transformational processes in the New Ukrainian School. The NAES of Ukraine researchers and university's academic staff discussed the urgent questions of reforming the general secondary education, exchanged the experiences in implementing the research results into educational practice. The session's participants got acquainted with the Faculty of Pedagogy activities, its innovative laboratories and centers.

Keywords: National Academy of Educational Sciences of Ukraine; Pereiaslav-Khmelnytskyi Hryhoriy Skovoroda State Pedagogical University; academic science; university science; the New Ukrainian School.

Дата публікації: 2 березня 2020 р. 